\title{
MOLEKUL
}

Articles

www.imolekul.com

https://doi.org/10.20884/1.jm.2020.15.2.586

\section{Anti-toxicity test of Peperomia pellucida steeping on liver function in diabetic-induced rat}

\author{
Saryono ${ }^{1 *}$, Hernayanti ${ }^{2}$, Atikah Proverawati ${ }^{3}$ \\ 'School of Nursing, Faculty of Health Sciences, Universitas Jenderal Soedirman, \\ Purwokerto, Indonesia \\ ${ }^{2}$ Faculty of Biology, Universitas Jenderal Soedirman, \\ Purwokerto, Indonesia \\ ${ }^{3}$ School of Nutrition, Faculty of Health Sciences, Universitas Jenderal Soedirman, \\ Purwokerto, Indonesia
}

*Corresponding author email: sarbiokim@gmail.com

Received October 07, 2019; Accepted May 30, 2020; Available online July 27, 2020

\begin{abstract}
Liver is important for both defense mechanism and protein synthesis in the human body. This study examined the anti-toxicity of Peperomia pellucida on liver function of diabetic-induced rats. It was an experimental study using pre- and posttest control group design. Rats were categorized into five groups, i.e., groups of healthy control (A), negative control (B), and treatment (C-E) with dosages of 150, 300, and $600 \mathrm{mg} / \mathrm{kg}$ of $P$. pellucida, respectively. Each group comprises of 5 rats. The TNF- $\alpha$, IL-12, and GSH were measured before and after a 14 days administration of $P$. pellucida. The data were analyzed by using one-way ANOVA test followed by Duncan's post hoc test with a significance level of $5 \%$. The result showed that $P$. pellucida steeping can improve liver cell damage, which was shown from the parameters of liver function, inflammation, and antioxidants. The mean of TNF- $\alpha$ and IL-12 levels decreased while the total protein, albumin, and GSH levels increased significantly after administration of $P$. pellucida steeping. Our study concluded that $P$. pellucida steeping might reduce TNF- $\alpha$ and IL-12 levels, and increased GSH level in diabetic-induced rat. A $300 \mathrm{mg} / \mathrm{kg}$ was the most effective dosage to reduce IL- 12 and increase GSH.
\end{abstract}

Keywords: anti-toxicity, GSH, IL-12, Peperomia pellucida, TNF- $\alpha$

\section{INTRODUCTION}

Liver has a strategic role for protecting the body and maintaining homeostasis. Continuous exposure xenobiotic compounds especially hepatotoxin have the detrimental effect on liver cells. Drugs, food/drink contaminated, or chemical pollution cause liver injury (Andrade \& Robles-Díaz, 2020; Teschke, Eickhoff, Brown, Neuman, \& Schulze, 2020). The prevalence of liver diseases is very high. About 2000 cases of acute liver failure occur in the United States per year and more than $50 \%$ of them are induced by drugs. Study in France showed about $13.9 \%$ of Drug Induced Liver Injury (Reuben, Koch, \& Lee, 2010). While study in a hospital in Tasikmalaya showed $96 \%$ of patients with impaired liver function were caused by drug side effect (Cinthya, Pradipta, \& Abdulah, 2012).

The use of drugs (pharmacological therapy) to restore liver cells actually is able to lead to toxicity and side effects. On the other hand, herbal therapy is increasingly in demand. It is safe to consume, cheap, affordable, and more likely to have less side effects.
One of the natural ingredients that can be utilized is Peperomia pellucida ( $P$. pellucida) plants. The previous research showed that $P$. pellucida contained flavonoids, tannins, steroids, alkaloids, and saponins (Idris, Olatunji, \& Madufor, 2016; and Ogunmoye, Oladosu, Olubomehin, Onajobi, \& Tijani, 2018).

$P$. pellucida steeping has been widely used as antioxidant, anti-hyperglycemia, and anti-dyslipidemia (Hamzah, Odetola, Erukainure, \& Oyagbemi, 2012; Rahmawati et al., 2020). The methanol extract of $P$. pellucida at dose of $400 \mathrm{mg} / \mathrm{kg}$ can increase antioxidant activity in white rats. Other research showed that $P$. pellucida extract at a dose of 300 $\mathrm{mg} / \mathrm{kg}$ was able to reduce blood glucose levels in diabetic rats (Sheikh et al., 2013). Even, at a dose of $4000 \mathrm{mg} / \mathrm{kg}$, P. pellucida did not cause acute liver toxicity (Waty, Saputri, \& Mun'im, 2017). However, research on $P$. pellucida steeping as antitoxicity has never been done. This study aimed to examine the antitoxicity of $P$. pellucida on liver function in diabeticinduced rats. 


\section{EXPERIMENTAL SECTION}

This was a true experiment study with a pre- and post-test with control group design. A total of 30 simple randomly selected rats were categorized into 5 groups, i.e., groups of healthy control (A), negative control (B), treatments (C-E) with dosages of 150,300 , and 600 $\mathrm{mg} / \mathrm{kg}$. The study was approved under the ethical clearance from the Faculty of Medicine, Padjadjaran University No. 1424/UN6.KEP/EC/2018.

\section{Preparation of experimental animals}

Wistar strain healthy and non deformed male rats aged 1.5-2 months, 150-200 grams were selected and adapted for a new environment for one week. Both $A D$ II standard pellet and drinks were provided ad libitum. Rats are placed in cages made of plastic boxes with lids made of woven wire. At the base of the cage was coated with $\pm 2 \mathrm{~cm}$ thick of husk. It was replaced every 2 days. Hence, the comfort and health of rats were maintained. Air circulation, temperature, and room lighting are regulated controlled as best as possible.

\section{Making a Peperomia pellucida steeping}

Fresh $P$. pellucida plants (leaves and stems) were washed under running water. Following withering process for 1 day, the washed plants were then dried directly under the sunlight for 7 days to obtain $1 \mathrm{~kg}$ dry plants $(0 \%$ water). Dried plants were stored in aluminum foil to keep it dry. The plant was brewed with boiling water making the dosage of 150,300 , and $600 \mathrm{mg} / \mathrm{kg}$, respectively. These dosages were dissolved to $3.6 \mathrm{ml} / 200$ grams of rat body weight. Brewed $P$. pellucida was dissolved with $200 \mathrm{ml}$ of warm water to easen the brewing process. Because of the conversion factor for $70 \mathrm{~kg}$ of human to $200 \mathrm{~g}$ of rat is 0.018 , the dosages 150,300 and $600 \mathrm{mg} / \mathrm{kg}$ of human body weight were converted to $1.665,3.333$, and 6.666 $\mathrm{g} / \mathrm{kg}$ rat body weight, respectively. Afterwards, these steeping were stirred and taken as many as 3.6 $\mathrm{ml} / 200 \mathrm{~g}$ of rat body weight.

\section{Phytochemical screening}

The phytochemical test was performed to identify polyphenols, tannins, saponins, and terpenoids. Flavonoid compound was tested quantitatively and qualitatively. The test was carried out by using standard procedures to identify the constituents as described in the previous study (Saryono \& Proverawati, 2018).

\section{Treatment of experimental animals}

Rats were injected with a single dose of streptozotocin (STZ) of $50 \mathrm{mg} / \mathrm{kg}$ intraperitoneally on the $8^{\text {th }}$ day to induce diabetic. Prior injection, rats were fasted for 6-8 hours. Streptozotocin was dissolved in $0.5 \mathrm{M}$ buffer citrate before hand (Sarie, Budirahardjo, \& Yuwono, 2016). Prior to and following the treatment of $P$. pellucida steeping, blood was taken for examination of total protein, globulin, albumin, TNF- $\alpha$, IL-12, and GSH. As many as $3 \mathrm{ml}$ of blood from the orbitalis plexus was drawn. It was then stored in a vacutainer. Treatment was given orally for 14 consecutive days every morning through a gastric tube.

A quantitative TNF- $\alpha$ and IL-12 plasma measurements were done with enzyme-linked immunosorbent assays using commercially available kits (BT Laboratories, Shanghai) according to the instructions available from the suppliers. Total protein, GSH, and albumin were measured by Biuret method (Dyasis kit, Germany), spectrophotometer (Biovision kit), Brom Cresol Green (BCG) method (Dyasis kit, Germany), respectively, while globulin was measured indirectly by substracting total protein to albumin.

\section{Statistical Data Analyses}

Normality of the data was tested by using the Saphiro-Wilk test. To find out the significant difference of normally distributed data for all groups, one-way ANOVA tests were done. The Duncan's Post-hoc analysis was then performed to determine the differences between each group and the most effective dose. Data was presented as the mean \pm standard deviation. $p$-Value $<0.05$ was considered significance.

\section{RESULTS AND DISCUSSION}

It was the first study to improving liver function of $P$. pellucida. Based on the phytochemical test, $P$. pellucida steeping contained polyphenols $(++)$, tannins $(+)$, saponins $(+)$, and terpenoids $(+)$. The main polyphenols were flavonoids. $P$. pellucida contained polyphenol with flavonoid compounds by $17.2 \mathrm{mg} / \mathrm{mL}$ and $15.6 \mathrm{mg} / \mathrm{mL}$, respectively. Previous study also showed that $P$. pellucida contained active substances such as flavonoids, alkaloids, saponins, and tannins (Majumder, 2012). Our study was in accordance with previous studies which showed that ethanol extracts of $P$. pellucida contains the main compounds, i.e., flavonoids, tannins and saponins (Sheikh et al., 2013). However, water extracts of $P$. pellucida contains steroids, alkaloids, and phenolics (Kalaiarasi, Johnson, Janakiraman, \& Sivaraman, 2016).

Statistical analysis showed that our data was normally distributed $(p>0.05)$ and homogeneous $(p>$ $0.05)$. ANOVA test showed that total plasma protein levels between the healthy control group and the diabetic-induced group ( $p<0.05$ ) were significant differences, but not between the diabetic-induced groups. There was a significant increase in total protein content $(p<0.05)$ after administration of $P$. pellucida (Figure 1). Post hoc LSD test showed that treatment group dose of $150 \mathrm{mg} / \mathrm{kg}$ was not significantly different to dose of $600 \mathrm{mg} / \mathrm{kg}$. It indicates that the 
dose of $150 \mathrm{mg} / \mathrm{kg}$ is a minimal dose of $P$. pellucida to increase total protein level.

The mean albumin level in the healthy control group was $3.41 \pm 0.14 \mathrm{mg} / \mathrm{dL}$. It was significantly different from diabetic-induced group $(p<0.05)$. After administration of $P$. pellucida steeping, the mean albumin level increased significantly (Figure 2). Post hoc LSD test demonstrated that there was no significant difference after treatment in the healthy control group and the treatment group doses of 300 and 600 $(p>0.05)$. However, there was a significant difference after treatment between NC, $\mathrm{Tl}$ and the other groups $(p<0.05)$. The 300 and $600 \mathrm{mg} / \mathrm{kg}$ dose groups had similar effect.

There were significant differences in the decrease of globulin levels between the study groups, the healthy control group, and the diabetic-induced group $(p<0.05)$. The biggest pre-post deviation was found in the T3 group by $0.30 \mathrm{mg} / \mathrm{dL}$ (Figure 3 ). The post hoc LSD test on deviation data showed there was no significant difference in the decrease in globulin levels between the T1, T2 and T3 groups, but it was significantly difference between the $\mathrm{HC}$ and $\mathrm{NC}$ groups $(\mathrm{p}<0.05)$.

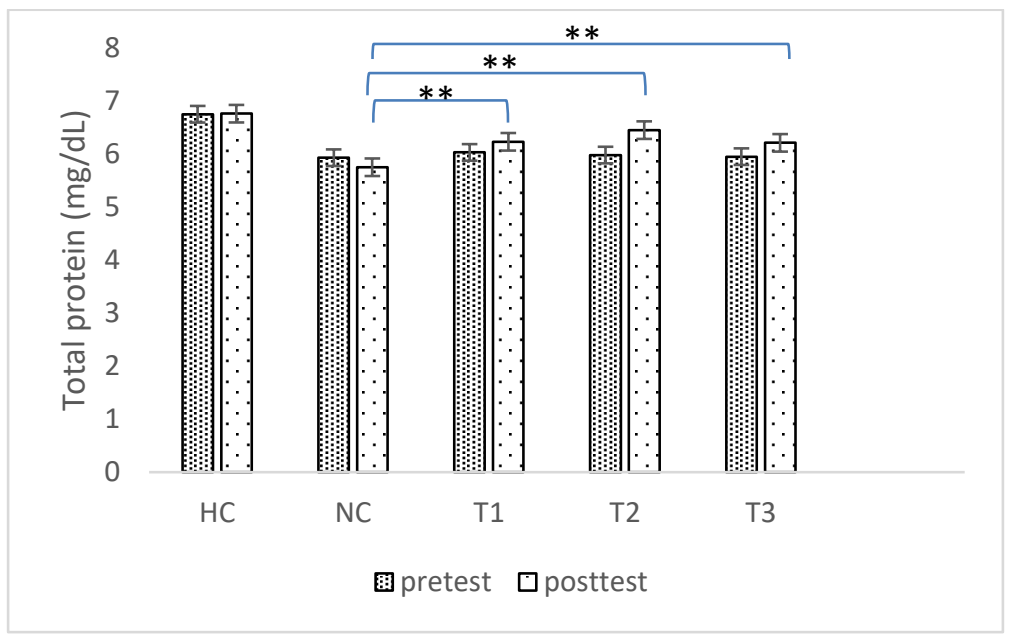

Figure 1. Total protein before and after administration of $P$. pellucida steeping. Before treatment, there was no difference in total protein levels between treatment groups, but significantly different from the healthy control group $(\mathrm{HC})$. After treatment, there were significant differences in total protein levels $(p<0.05)$. HC: healthy control; NC: negative control. T1-T3: groups treated with $P$. pellucida with doses of 150,300 and $600 \mathrm{mg} / \mathrm{kg}$, respectively. ${ }^{* *} p<0.01$. (least significant difference (LSD) test).

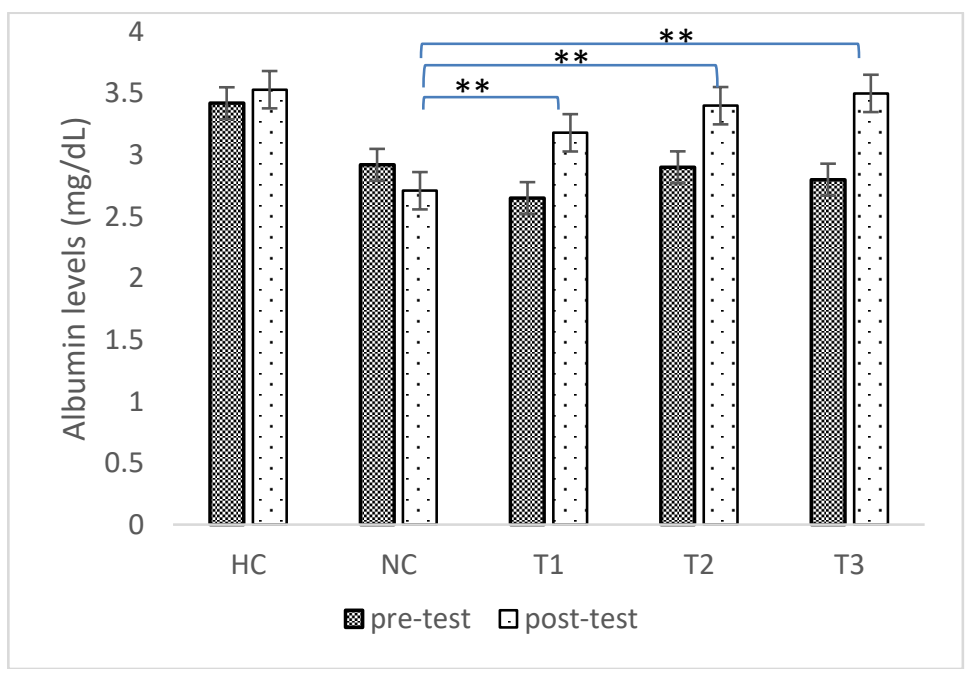

Figure 2. Albumin levels before and after the treatment of $P$. pellucida steeping. HC: healthy control; NC: negative control. T1-T3: groups treated with P. pellucida dose of 150, 300 and $600 \mathrm{mg} / \mathrm{kg}$ respectively. ${ }^{* *} \mathrm{p}<0.01$. (least significant difference (LSD) test). 


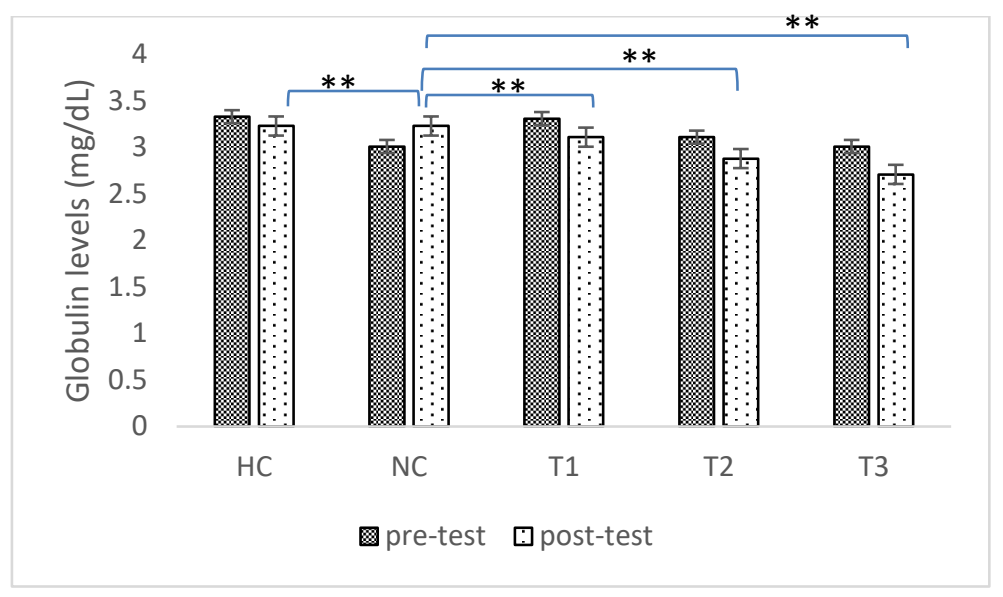

Figure 3. Globulin levels before and after the treatment of $P$. pellucida steeping. HC: healthy control; NC: negative control. T1-T3: groups treated with P. pellucida dose of 150, 300 and $600 \mathrm{mg} / \mathrm{kg}$, respectively. ${ }^{*} \mathrm{p}<0.05,{ }^{* *}<0.01$. \{least significant difference (LSD) test\}.

Lipid peroxidation in the liver cell membrane damages cell membrane integrity and worsen cell injury (Saryono, Sumeru, Proverawati, \& Efendi, 2018). Prolonged liver cell injury causes cell damage to death, leading to liver failure. Liver function disruption causes various complications such as total protein, albumin and globulin deficiency, oedema, disruption of fluid, and electrolyte regulation. Reactive oxygen species will cause free radical chain reactions. Superoxide radicals are toxic because they are able to form hydroxyl radicals and react to nitric oxide (NO) to form peroxynitrite radicals (ONOO-). In addition, the STZ induction triggers oxidative stress, due to an imbalance between free radicals and antioxidants (Mondal, Das, Junejo, Borah, \& Zaman, 2016).

$P$. pellucida contains phenolic compounds, such as flavonoids with antioxidant activity (Ayu, Catur, Muhamad, Eljabbar, \& Ketut, 2018). This will repair liver cell damage. Phenolic compounds work as free radical scavengers, through the $\mathrm{H}^{+}$donor from hydroxyl groups $(\mathrm{OH})$ in flavonoids against free radical compounds to form stable molecules (Ferraz et al., 2020; Mutee et al., 2010; Saryono et al., 2017). Previous studies showed that flavonoids in herb plants are useful for chelating free radicals by increasing endogenous antioxidant enzymes, reducing free radicals, and donating atoms. Hence free radical chain reactions are disrupted (Beltran-Benjamin, Co, Gaspi, Matibag, \& Sia Su, 2013). Recent studies also showed that the methanol extract of $P$. pellucida has a potent antioxidant activity (Rhaman, Islam, \& Shoeb, 2019).

Initial data (prior to $P$. pellucida administration) showed a significant difference in TNF- $\alpha$ levels between the diabetic-induced and the healthy control group $(p<0.05)$. TNF- $\alpha$ levels experienced a significant increase after a STZ induction (Figure 4). While, after administering $P$. pellucida steeping treatment, TNF- $\alpha$ levels significantly decrease. There was a significant difference in TNF- $\alpha$ levels between treatment groups $(p<0.05)$. The post hoc LSD test results from post test data showed that there were significant differences between the T1, T2, and T3 groups $(p<0.05)$, except for $\mathrm{T} 1$ to $\mathrm{T} 2$.

Streptozotocin-exposed hepatocyte cell membrane experiences lipid peroxidation. Streptozotocin produces more free radical compounds due to an increase of reactive oxygen species (ROS) (Ruiz et al., 2019). High levels of free radicals will reduce endogenous antioxidant enzymes, such as GSH, catalase, and superoxide dismutase. As a source of free radicals, STZ will cause damage resulting in inflammation that increases inflammatory indicators, such as TNF- $\alpha$ and IL-12 (Saryono, Warsinah, \& Isworo, 2018).

There were significant differences of the reduction of IL-12 levels between groups $(p<0.05)$ (Figure 5). Post hoc test on post test data showed that there were no differences between the T2 and T3 groups, but there were differences between others. The greatest reduction of IL-12 was found in the T3 group. This shows that a dose of $600 \mathrm{mg} / \mathrm{dL}$ was able to reduce IL-12 optimally.

$P$. pellucida treatment are also able to inhibit the activity of NF-kB (Nuclear Factor Kappa B), COX2, and prostaglandin synthesis leading to the decrease of proinflammatory mediators (Van De Wier, Koek, Bast, \& Haenen, 2017). Previous studies also showed that the $P$. pellucida extract reduce TNF- $\alpha$ and IL-12 (Finato et al., 2018). P. pellucida extract in doses of 100 and 200 $\mathrm{mg} / \mathrm{kg}$ significantly increase white blood cells (WBCs) (Florence et al., 2017) as well the inflammatory rate in the liver cells. Other study showed that flavonoids reduce TNF- $\alpha$ NF-kB and IL-1 $\beta$ expression in liver tissue (Liv et al., 2020). 


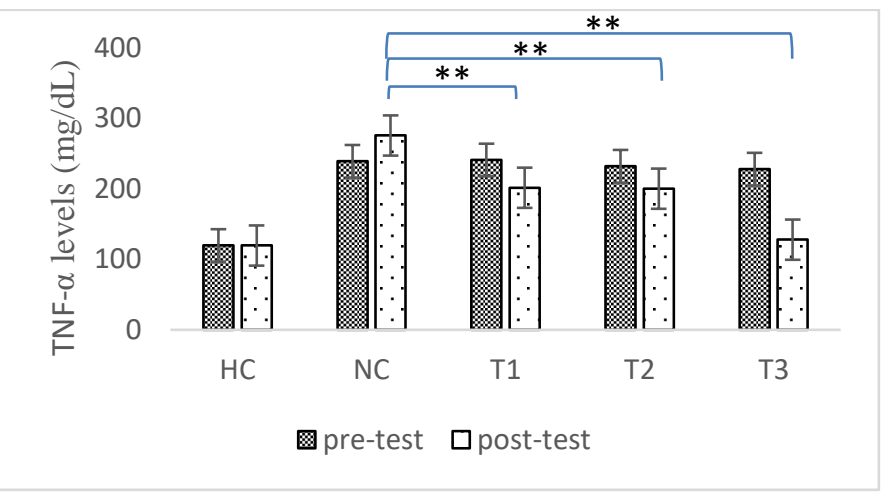

Figure 4. TNF- $\alpha$ levels before and after treatment with $P$. pellucida steeping. HC: healthy control; NC: negative control. T1-T3: groups treated with P. pellucida dose of 150, 300 and $600 \mathrm{mg} / \mathrm{kg}$ respectively. ${ }^{*} \mathrm{p}<0.05,{ }^{* *}<0.01$. \{least significant difference (LSD) test\}.

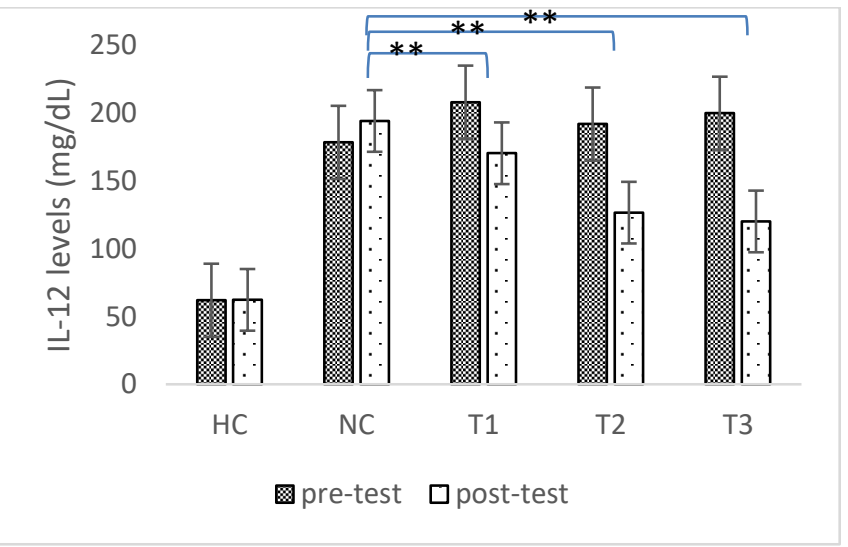

Figure 5. IL-12 levels before and after treatment with P. pellucida steeping. HC: healthy control; NC: negative control. T1-T3: groups treated with $P$. pellucida dose of 150, 300 and $600 \mathrm{mg} / \mathrm{kg}$ respectively. ${ }^{*} p<0.05,{ }^{* *}<0.01$. \{least significant difference (LSD) test\}.

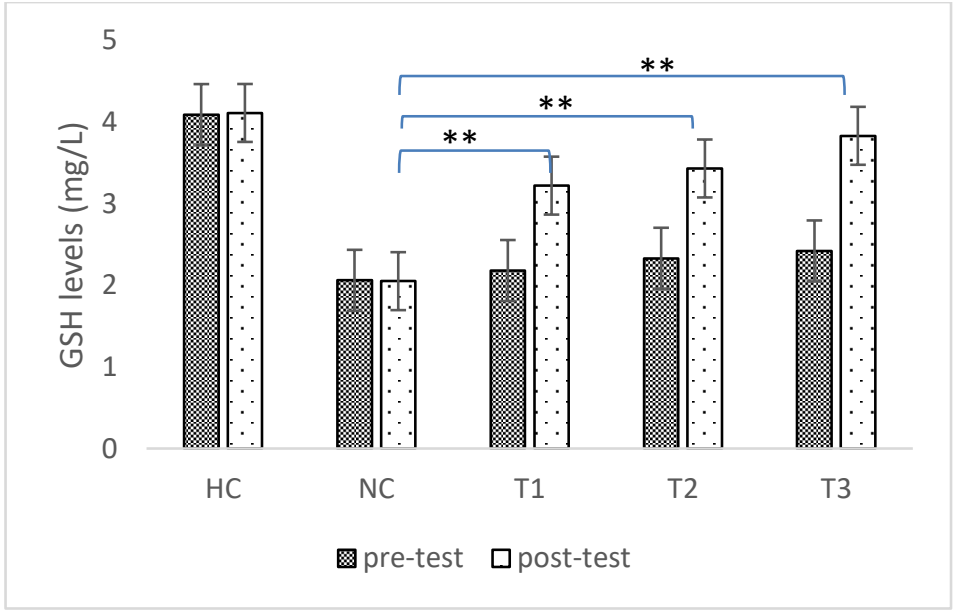

Figure 6. GSH levels before and after treatment with P. pellucida steeping. HC: healthy control; NC: negative control. T1-T3: groups treated with P. pellucida dose of 150,300 and $600 \mathrm{mg} / \mathrm{kg}$ respectively. ${ }^{*} p<0.05,{ }^{* *}<0.01$. \{least significant difference (LSD) test\}. 
There were significant differences in GSH deviation level between groups $(p<0.05)$. The highest increment of GSH level occurred in the T3 group at $1.40 \mathrm{mg} / \mathrm{dL}$ (Figure 6). The post hoc LSD test results showed that there were no differences of the GSH deviation between $\mathrm{T} 1$ and $\mathrm{T} 2$, but were significantly different from the T3, HC, and NC groups ( $p<0.05)$.

Flavonoids increase endogenous antioxidant defenses such as GSH (glutathione reductase) by donating $\mathrm{H}^{+}$. It reduces inflammation processes through the inhibition of ONOO- (peroxynitrite) (Chen, Lü, Yao, \& Chen, 2016). GSH eliminates free radicals by converting various hydrogen peroxide and lipid peroxide into water. Flavonoids work by donating hydrogen atoms to peroxyl radicals to form flavonoid radicals, which easily react to free radicals. Hence, the radical chain reaction is completely disrupted. Recent studies have shown that flavonoids act as antiinflammatory (Ahmed et al., 2020; Kartika, Insanu, Safitri, Putri, \& Adnyana, 2016; Zubair, Samiya, Jalal, \& Mostafizur, 2015).

Many studies have also shown that $P$. pellucida of $10 \% \mathrm{w} / \mathrm{w}$ and $20 \% \mathrm{w} / \mathrm{w}$ of $P$. pellucida mixed with 900 $\mathrm{g}$ and $800 \mathrm{~g}$ of standard rat feed combined with glibenclamide, respectively causes an increase in SOD, catalase and GSH. This confirms that the $20 \% \mathrm{w} / \mathrm{w}$ suplement is more effective than the $10 \% \mathrm{w} / \mathrm{w}$ supplement in increasing SOD levels (Hamzah et al., 2012). Flavonoids and tannins have hydroxyl groups ($\mathrm{OH}$ ) to be donated to $\mathrm{O}_{2} \cdot$. Thus, they become neutral. In addition, the consumption of water-based supplements can increase GSH, which serves as a defense against oxidative stress by means of GSH oxidized to GSSG, and then GSSG is reduced again to GSH assisted by glutathione reductase. The component of flavonoids is able to become fat-soluble chain breaking antioxidants working on cell membranes to break the lipid peroxidation chain (Saryono, Taufik, Proverawati, \& Efendi, 2019). The effects of flavonoids on ROS occur through two mechanisms, i.e. 1) by capturing free radicals/neutralizing and 2) by increasing endogenous antioxidants such as SOD (Panich, Ananta, Onkoksoong, \& Jaemsak, 2007).

This study did not examine the differences in temperature during the making of $P$. pellucida steeping. Temperature differences in the process of drying and storing affect $P$. pellucida contents such as vitamin $\mathrm{C}$ and flavonoids as proven in other studies (Minh, 2019).

\section{CONCLUSIONS}

Our findings showed that $P$. pellucida steeping was able to improve liver cells function by reducing TNF- $\alpha$, IL-12, and GSH levels in diabetic-induced rats. Our study also showed that the most effective dose of $P$. pellucida steeping was the $300 \mathrm{mg} / \mathrm{kg}$ with the highest reduction in TNF- $\alpha$, IL-12, and GSH. Hepatic histopathology testing is necessary to ensure the improved hepatic cells.

\section{ACKNOWLEDGEMENTS}

The authors thank to Yunita Sari for providing assistance in English editing.

\section{REFERENCES}

Ahmed, S., Ahmed, N., Rungatscher, A., Linardi, D., Kulsoom, B., Innamorati, G., ... Faggian, G. (2020). Cocoa flavonoids reduce inflammation and oxidative stress in a myocardial ischemiareperfusion experimental model. Antioxidants, 9(2). https://doi.org/10.3390/antiox9020167

Andrade, R. J., \& Robles-Díaz, M. (2020). Diagnostic and prognostic assessment of suspected druginduced liver injury in clinical practice. Liver International, 40(1), 6-17. https://doi.org/10.1111/liv.14271

Ayu, K. I. G. A., Catur, R., Muhamad, I., Eljabbar, L. F. D., \& Ketut, A. I. (2018). Sasaladaan (Peperomia pellucida [L.] Kunth.) extracts improve trabecular bone microarchitecture in ovariectomy-Induced osteoporotic rats. International Journal of Green Pharmacy, 12(4), 624-628.

Beltran-Benjamin, K. S., Co, E. L., Gaspi, S. A. D., Matibag, J. L. R., \& Sia Su, G. L. (2013). Enzyme activity and histopathology of rat liver treated with crude methanolic extract of Pepperomia pellucida (L.) HBK. Journal of Biological Sciences. https://doi.org/10.3923/ibs.2013.183.195

Chen, A. Y., Lü, J.-M., Yao, Q., \& Chen, C. (2016). Entacapone is an antioxidant more potent than vitamin $C$ and vitamin $E$ for scavenging of hypochlorous acid and peroxynitrite, and the inhibition of oxidative stress-induced cell death. Medical Science Monitor, 22, 687-696. https://doi.org/10.12659/msm.896462

Cinthya, S. E., Pradipta, I. S., \& Abdulah, R. (2012). Penggunaan obat penginduksi kerusakan hati pada pasien rawat inap penyakit hati. Jurnal Farmasi Klinik Indonesia, 1(2), 4-9.

Ferraz, C. R., Carvalho, T. T., Manchope, M. F., Artero, N. A., Rasquel-Oliveira, F. S., Fattori, V., ... Verri, W. A. (2020). Therapeutic potential of flavonoids in pain and inflammation: Mechanisms of action, pre-clinical and clinical data, and pharmaceutical development. Molecules, 25(3), 1-35. https://doi.org/10.3390/molecules25030762

Finato, A. C., Fraga-Silva, T. F., Uliana Carvalho Prati, A., Alves de Souza, A., Mazzeu, B. F., Felippe, L. G., ... Venturini, J. (2018). Crude leaf extracts of piperaceae species down modulate inflammatory 
responses by human monocytes. PLoS ONE, 13(6), $1-14$. https://doi.org/10.1371/journal.pone.0198682

Florence, N. T., Huguette, S. T. S., Hubert, D. J., Raceline, G. K., Desire, D. D. P., Pierre, K., \& Theophile, D. (2017). Aqueous extract of Peperomia pellucida (L.) HBK accelerates fracture healing in wistar rats. BMC Complementary and Alternative Medicine, 17(1), 1-9. https://doi.org/10.1186/s12906-017-1686-3

Hamzah, R. U., Odetola, A. A., Erukainure, O. L., \& Oyagbemi, A. A. (2012). Peperomia pellucida in diets modulates hyperglyceamia, oxidative stress and dyslipidemia in diabetic rats. Journal of Acute Disease, 1(2), 135-140. https://doi.org/10.1016/S2221-6189(13)600311

Idris, O. O., Olatunji, B. P., \& Madufor, P. (2016). In vitro antibacterial activity of the extracts of Peperomia pellucida ( L ). British Microbiology Research Journal, 11(4), 1-7. https://doi.org/10.9734/BMRJ/2016/21421

Kalaiarasi, V., Johnson, M., Janakiraman, N., \& Sivaraman, A. (2016). Phytochemical and antibacterial studies on Peperomia pellucida (L.) HBK. International Journal of Pharmaceutical Science and Research, 1(1), 4-6.

Kartika, I., Insanu, M., Safitri, D., Putri, C., \& Adnyana, I. (2016). New update: traditional uses, phytochemical, pharmacological and toxicity review of Peperomia pellucida ( L .) kunth. Pharmacology Online, 2, 30-43.

Liv, T., Tan, F., Long, X., Pan, Y., Mu, J., Zhou, X., ... Zhao, X. (2020). Improvement effect of lotus leaf flavonoids on carbon tetrachloride-induced liver injury in mice. Biomedicines, 8(41), 1-12.

Majumder, P. (2012). Evaluation of taxo-chemical standardization and quality control parameters of Peperomia pellucida (Family: Piperaceae): A multi valuable medicinal herb. Journal of Pharmaceutical and Scientific Innovation, 1(6), 712.

Minh, N. P. (2019). Herbal tea production from peperomia pellucida leaf. Plant Archives, 19, 449-451.

Mondal, P., Das, S., Junejo, J. A., Borah, S., \& Zaman, K. (2016). Evaluations of antidiabetic potential of the hydro-alcoholic extract of the stem bark of Plumeria rubra a traditionally used medicinal source in North-East India. International Journal of Green Pharmacy, 10(04), 252-260. https://doi.org/10.22377/iigp.v10i04.763

Mutee, A. F., Salhimi, M. F., Yam, C. P., Lim, G. Z., Abdullah, O. Z., Ameer, M. F., ... Asmawi. (2010). In vivo Anti-inflammatory and in vitro antioxidant activities of Peperomia pellucida. International Journal of Pharmacology, 6(5), 686690.

Ogunmoye, A. O., Oladosu, I. A., Olubomehin, O. O., Onajobi, I. B., \& Tijani, S. (2018). Antimicrobial activities of essential oils from Peperomia pellucida (Linn.) leaf obtained in Nigeria. J. Chem Soc. Nigeria, 43(4), 872-878.

Panich, U., Ananta, W., Onkoksoong, T., \& Jaemsak, K. (2007). Effects of cellular uptake of flavonoids against peroxynitrite-mediated cell cytotoxicity. Siriraj Medical Journal, 59(5), 237-241.

Rahmawati, N., Widiyastuti, Y., Purwanto, R., Lestari, S. S., Sene, H. A., \& Bakari, Y. (2020). Medicinal plants used by traditional healers for the treatment of various diseases in ondae sub-ethnic of Poso District in Indonesia. In Advances in Health Sciences Research, 4th International Symposium on Health Research (ISHR 2019) (Vol. 22, pp. 460-468). Atlantis Press.

Reuben, A., Koch, D. G., \& Lee, W. M. (2010). Druginduced acute liver failure: results of a U.S. multicenter, prospective study. Hepatology, 52, 2065-2076. https://doi.org/10.1002/hep.23937

Rhaman, M., Islam, N., \& Shoeb, M. (2019). Bioactivity of peperomia pellucida leaves from Bangladesh. American Journal of Biomedical Science \& Research, 6(1), 520-522. https://doi.org/10.34297/ajbsr.2019.06.000981

Ruiz, F. M. H. P., Barrera, A. F., Alquicira, E. P., Almanza Pérez, J. C., Ramos, R. R., \& Santos, J. S. (2019). Antihyperglycemic, antioxidant and anti-inflammatory effects of aqueous extract of mistletoe (Cladocolea loniceroides) in STZinduced diabetic mice. African Journal of Traditional, Complementary and Alternative Medicine, 16(1), 1-12. https://doi.org/10.21010/ajtcam.v16i1.1

Sarie, V. P., Budirahardjo, R., \& Yuwono, B. (2016). Efektivitas seduhan daun yakon (Smallanthus sonchifolius) terhadap kadar low density lipoprotein (LDL) dan high density lipoprotein (HDL) pada tikus diabetik yang diinduksi streptozotocin. e-Jurnal Pustaka Kesehatan, 3(3), 542-546.

Saryono, S., Eliyan, J., Herdiati, D., Khikmatullah, A., Silvana, C., \& Adi, H. (2017). Anti-atherogenic properties of deglet noor date seeds (Phoenix dactylifera) methanol extract on diet-induced hypercholesterolemic rats. IOP Conference Series: Materials Science and Engineering, 172(1). https://doi.org/10.1088/17426596/755/1/011001

Saryono, S., \& Proverawati, A. (2018). The effects of anti-atherogenic properties of beverage of the 
date seeds (Phoenix dactilifera L.) in premenopause women: A study of Indonesian women. Transylvanian Review, 26(29).

Saryono, S., Sumeru, A., Proverawati, A., \& Efendi, F. (2018). Decreasing carbon tetrachloride toxicity using date-seed (Phoenix dactylifera L .) steeping in rats. Toxicol. Environ. Health. Sci., 10(2), 139$145 . \quad$ https://doi.org/10.1007/s13530-0180357-1

Saryono, S., Taufik, A., Proverawati, A., \& Efendi, F. (2019). Dietary supplementation of Phoenix dactylifera L. seeds decreases pro-inflammatory mediators in $\mathrm{CCl} 4$-induced rats. Journal of Herbmed Pharmacology, 8(3), 1-6. https://doi.org/10.15171/jhp.2019.xx

Saryono, S., Warsinah, W., \& Isworo, A. (2018). Antiinflammatory effect of date seeds (Phoenix dactylifera L) on carrageenan-induced edema in rats. Tropical Journal of Pharmaceutical Research, 17(12), 2455-2461. https://doi.org/10.4314/tipr.v17i12.22

Sheikh, H., Sikder, S., Paul, S. K., Hasan, A. . R., Rahaman, M. M., \& Kundu, S. P. (2013). Hypoglycemic, anti-inflammatory and analgesic activity of Peperomea Pellucida (L.) HBK (Pieraceae). International Journal of
Pharmaceutical Sciences and Research, 4(1), 458-463.

Teschke, R., Eickhoff, A., Brown, A. C., Neuman, M. G., \& Schulze, J. (2020). Diagnostic biomarkers in liver injury by drugs, herbs, and alcohol: Tricky dilemma after ema correctly and officially retracted letter of support. International Journal of Molecular Sciences, $21(1)$. https://doi.org/10.3390/ijms21010212

Van De Wier, B., Koek, G. H., Bast, A., \& Haenen, G. R. M. M. (2017). The potential of flavonoids in the treatment of non-alcoholic fatty liver disease. Critical Reviews in Food Science and Nutrition, 57(4),

834-855. https://doi.org/10.1080/10408398.2014.95239 9

Waty, D. R., Saputri, F. C., \& Mun'im, A. (2017). Secondary metabolites screening and acute toxicity test of Peperomia pellucida (L.) kunth methanolic extracts. International Journal of PharmTech Research, 10(1), 31-38.

Zubair, K. L., Samiya, J. J., Jalal, U., \& Mostafizur, R. (2015). In vitro investigation of antidiarrhoeal, antimicrobial and thrombolytic activities of aerial parts of Peperomia pellucida. Pharmacologyonline, 3(2015-December), 5-13. 